Publ. No. 3, Sask. Nat. Hist. Soc., Regina. $75 \mathrm{p}$.

Godfrey, W. E. 1950. Birds of the Cypress Hills and Flotten Lake regions, Saskatchewan. Nat. Mus. of Can., Bull. No. 120, Ottawa. $96 \mathrm{p}$.

Houston, C. S., and M. G. Street. 1959. The birds of the Saskatchewan River, Carlton to Cumberland. Sask. Nat. Hist. Society, Special Publ. No. 2, Regina. 205 p.

Lawrence, A. G. 1965. Field checking list of Manitoba birds. Nat. Hist. Society of Manitoba and Manitoba Mus. Assoc.

Lloyd, H. 1961. A Manitoba occurrence of the
Black-headed Grosbreak. Can. Field-Nat., 75 : 109.

Mitchell, H. H. 1924. Birds of Saskatchewan. Can. Field-Nat., $38: 101-118$.

Mossop, H. 1955. Chickadee Notes, No. 18. Winnipeg Free Press. May 20, 1955.

Peterson, R. T. 1961. A field guide to western birds. Second ed. Houghton Mifflin, Boston.

Pough, R. H. 1957. Audubon western bird guide. Doubleday and Co., Garden City, New York.

West, D. A. 1962. Hybridization in grosbeaks (Pheucticus) of the Great Plains. Auk, 79 : 399-424.

\title{
SUMMER RECORD OF A SNOWY OWL
}

\author{
by Garry L. Fletcher, Conquest
}

The following is an account of my capture of a female adult Snowy Owl on June 14, 1964. The owl was first observed near MacDonald's Creek, two miles west of Bounty, Saskatchewan, flying about 10 to 15 feet above the ground at a distance of a quarter of a mile.

There were four other people with me at the time, and we had been casually walking in a stony pasture looking for tipi rings. At first, not

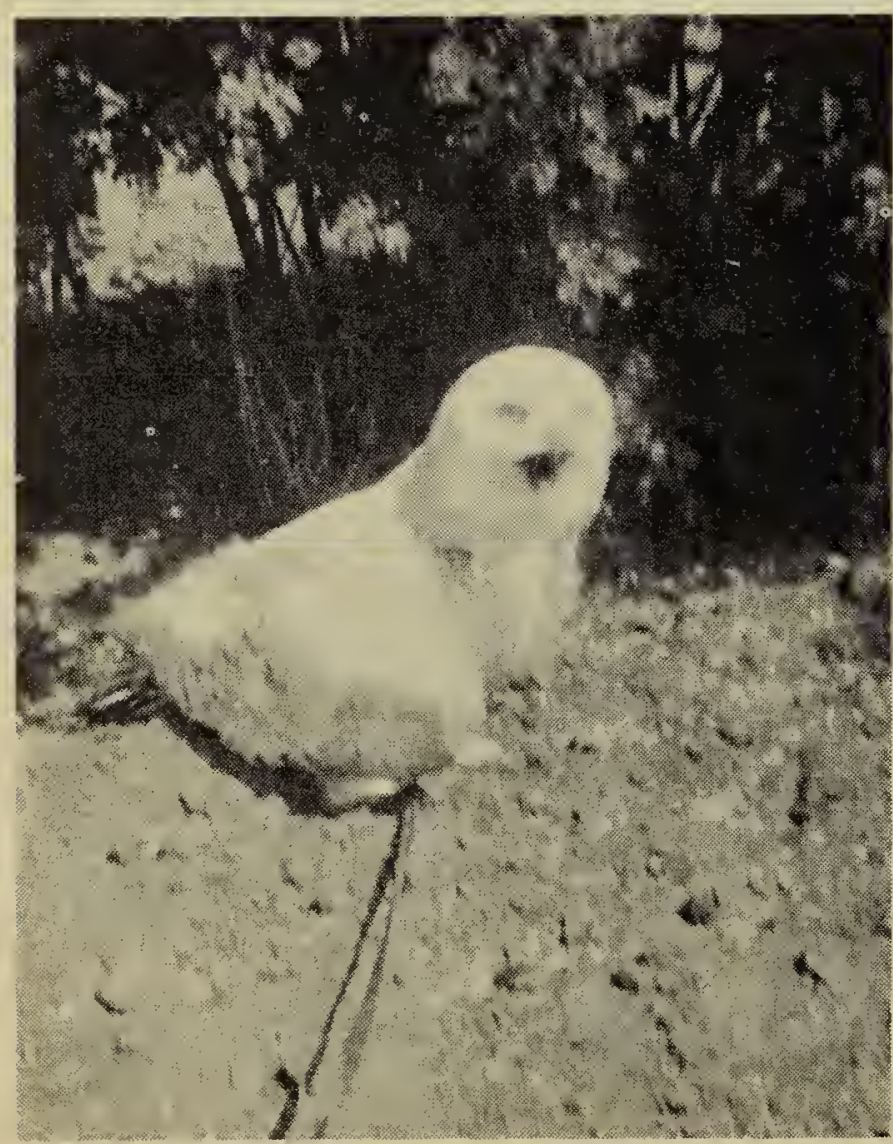

Photo by Garry L. Fletcher thinking of a Snowy Owl being around in the summer, we expected it to be some large white water bird, but after approaching to within several hundred yards, we soon recognized it as an owl. When it lit on an open piece of ground near the creek, two of us decided to circle around it to get a better look. The nearer we approached the more bewildered it got until I managed to wrap a coat around it from behind. Of course, after having seen it fly we had never expected to catch it. We didn't realize what was wrong with it until I had got it home and in a pen. Then it was evident that the right wing was not tucked in as close to its body as was the left one. Closer examination showed that the main bend of the wing had been broken and had healed almost perfectly. The bird appeared in otherwise excellent condition. Being near the water had likely helped it to survive, by way of providing easy-to-catch shorebirds and other small game. We noticed that in the place where we caught the bird several Willets were making quite a fuss, apparently disturbed over the presence of the owl.

I kept the owl for a week, feeding it scraps of raw meat and dead House Sparrows. The latter, I might add, were consumed whole, in one gulp. On June 20, I brought the owl to the Wild Animal Park in Saskatoon, where I left it to live with the two other Snowy Owls that were there. 